\title{
The mnemonic qualities of textiles: Sustaining lifelong attachment
}

\author{
Emma Peters
}

\begin{abstract}
This paper uses Jonathon Chapman's theory of emotionally durable design to explore how memory is invested in and lends value to textile artefacts, thus ensuring their enduring preservation. Through an examination of the works of Elisa Markes-Young, John Parkes, Sara Lindsay and Ilka White, the paper argues that a greater understanding of objects with mnemonic qualities provides new ways of challenging object obsolescence for art and design practice, thus offering a model for sustainable design.
\end{abstract}

\section{Introduction}

Sustainable design is not only concerned with the physical qualities of an object, but with the experience and meaning invested by its owners that stimulates memory, develops connection and value, and subsequently ensures the object's enduring existence. Sustainable design incorporates social, economic and environmental factors into the creation of objects, environments and services, and is informed by seminal writers such as Victor Papanek (1985) and William McDonough and Michael Braungart (2002).

The emotional considerations raised by sustainable design have motivated new approaches to the creation of objects. The theory of emotionally durable design, developed by Jonathon Chapman (2005), reconsiders design thinking to encompass the potency of emotional attachment to objects. The theory underpins this paper's premise that mnemonic relationships between humans and objects have an effect upon sustainable practice.

This paper is concerned with handcrafted personal possessions that are associated with individual and family memory. There is much literature on public memorial sites and objects and the ways in which they embody collective memory (cf. Stewart 1984; Nora 1989; Bennett 2003; Rowlands \& Tilley 2006;). Mnemonic qualities of privately owned objects are acquired once we confer our personal stories and experiences upon them. An object has no faculty for memory (Kwint et al. 1999), however, it can be associated with memory. Interactions with a mnemonically enriched object can activate memory and its accompanying emotions. The capacity for an object to accept the investment of memory on the part of its owner can contribute to building this connection. In this paper, I will use M.L. Richin's writing on possession meaning (1994: 504-21), French sociologist Violette Morin's work on the biographical object (1969 cited 
in Hoskins 1998: 8-11), and D.W. Winnicott's theory of the transitional object (1984: 229-42) to build on a discussion of the types of meaningful relationships we have with mnemonic objects.

I am a contemporary textile practitioner and my work seeks to understand the particular qualities of cloth that foster the development of enduring mnemonic relationships. The social nature of cloth allows for the effortless transference of personal memories. Haptic interaction begins soon after birth and continues until death. Cloth lies next to the surface of our skin for most hours of the day, providing protection, insulation and a means to express or disguise ourselves. Those who recognise in handmade textiles the signs of skilled workmanship and investment of time regard such artefacts worthy of memory association. As R.W. Belk (1990: 671-72) states, we demand the authenticity and uniqueness of an object before it can become representative of our significant personal memories. I propose that cloth's haptic quality, and its intimate and daily connection with our lives, provide a relevant domain for the study of mnemonic objects.

The paper explores the way in which Australian textile artists Elisa MarkesYoung, Ilka White, Sara Lindsay and John Parkes work with links between textiles and memory. I argue that their focus on memory and emotional connection to textiles offers a model for more permanent ways to value designed objects, allowing them to operate as examples of emotionally durable design.

\section{Memory and emotionally durable objects}

Chapman's theory of emotionally durable design is a response to the urgent need to address sustainability in the creative fields. He endeavoured to look beyond reactionary solutions, such as recycling, by developing a deeper philosophical design foundation to reduce rubbish and landfill.

Our challenge as designers, artists, makers and consumers is to resolve issues of obsolescence without compromising the environment. The fundamental concern, as Chapman points out, is the preservation of user engagement with the object over long periods of time, and ideally, as close to forever as possible. To achieve this, the future 'life' of the object needs to be considered in terms of material quality, workmanship, functionality and the object's ability to engage emotionally over time (Chapman 2005: 112). The emotional engagement that results from the mnemonic qualities of an object can effectively contribute to an object's longevity.

Neuroanatomical evidence shows how emotion has influence upon the formation, consolidation and retrieval of memory (Buchanan \& Adolphs 2004). More significantly, the retrieval of memory involved in reminiscence can generate an emotional response. Psychologists describe this as one of the directive functions of memory (Philippe et al. 2011). Remembering has an impact upon our current emotional state (LeDoux 1992; Schwartz, Weinberger \& Singer 1981, cited in Philippe et al. 2011), and is based upon how the original experience was perceived 
(Deci \& Ryan 2000, cited in Philippe et al. 2011). In the instance of objects triggering memory, the subsequent emotion is an affective one. Memory sustains self-identity, and consequently engenders a greater sense of value for the object.

\section{Layers of memory over time}

Markes-Young, a Polish-born German artist residing in Perth, explores concepts of memory through textiles, and discusses her inherited tablecloth and set of pillowcases that display characteristics of emotionally durable design. The tablecloth is embellished with traditional embroidery techniques of white and black stitch (herringbone, satin-stitch, buttonhole wheels) upon crisp white linen. The ornamental stitching was begun by the artist's great-grandmother, continued by her grandmother and mother and is yet to be 'finished'. The pillowcase, also in white linen, has an intricate filet lace panel. Markes-Young has repurposed the pillowcases with the addition of a second, larger piece of white fabric to act as curtains in her home. She recounts the origins of both pieces:

My mother was generous enough to give me a few pieces from her collection when I left home. I love them all, but one of my favorites is a tablecloth that my great-grandmother made, or rather started to make, because it's still unfinished (Figure 6). It consists of nine embroidered pieces of linen. My mother did some work on it years ago but the pieces still need to be joined. Maybe l'll do it one day. Or maybe I will use them to make something else, as in the case of the pillowcases with filet lace that became curtains for my kitchen window. (Markes-Young 2013)

It is rare for an object to survive beyond one generation of a family. MarkesYoung's tablecloth and curtain have existed across four generations and two continents. These pieces possess key characteristics of Chapman's emotionally durable design theory. Emotionally durable design places emphasis on an object's capacity to acquire new significance as it passes from owner to owner. It also values the marks of wear an object acquires over time. The quality of the linen fabric has ensured the physical survival of Markes-Young's pieces, and skilled stitch work has encouraged each owner to invest in preservation of the fabric. The yielding quality of the tablecloth and pillowcases have allowed for each owner to add their own embroidery stitch. The function of the pillowcases has been modified to suit new contexts, environments and eras. The pieces have also been charged with each owner's personal memories and experiences, layering and reconfiguring existing meaning. The longer the textiles last through repurposing and remaking, the more meaningful they become. The emotional and mnemonic qualities ensure that objects are valued and treasured for ongoing periods of time. 


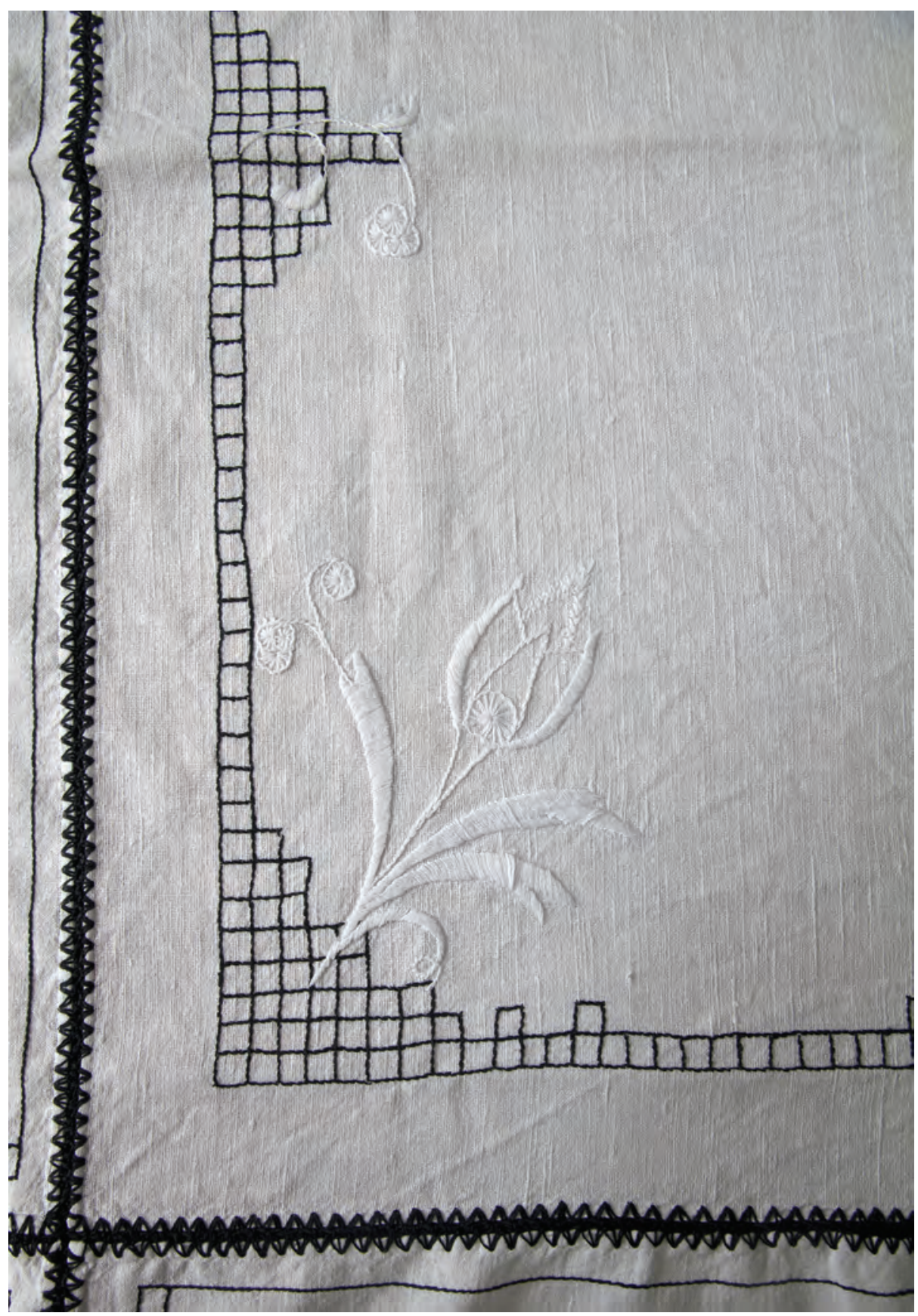

Figure 1. Tablecloth, n.d., black and white cotton thread on linen, outline, herringbone and satin stitch, buttonhole wheels, crocheted edging, approx. 1200 x $1450 \mathrm{~mm}$. From the collection of Elisa Markes-Young, started by Stanisława Leciejewska, embroidery continued by her daughter Aniela Hadasik, continued by Renata Markes

Photo: Christopher Young 


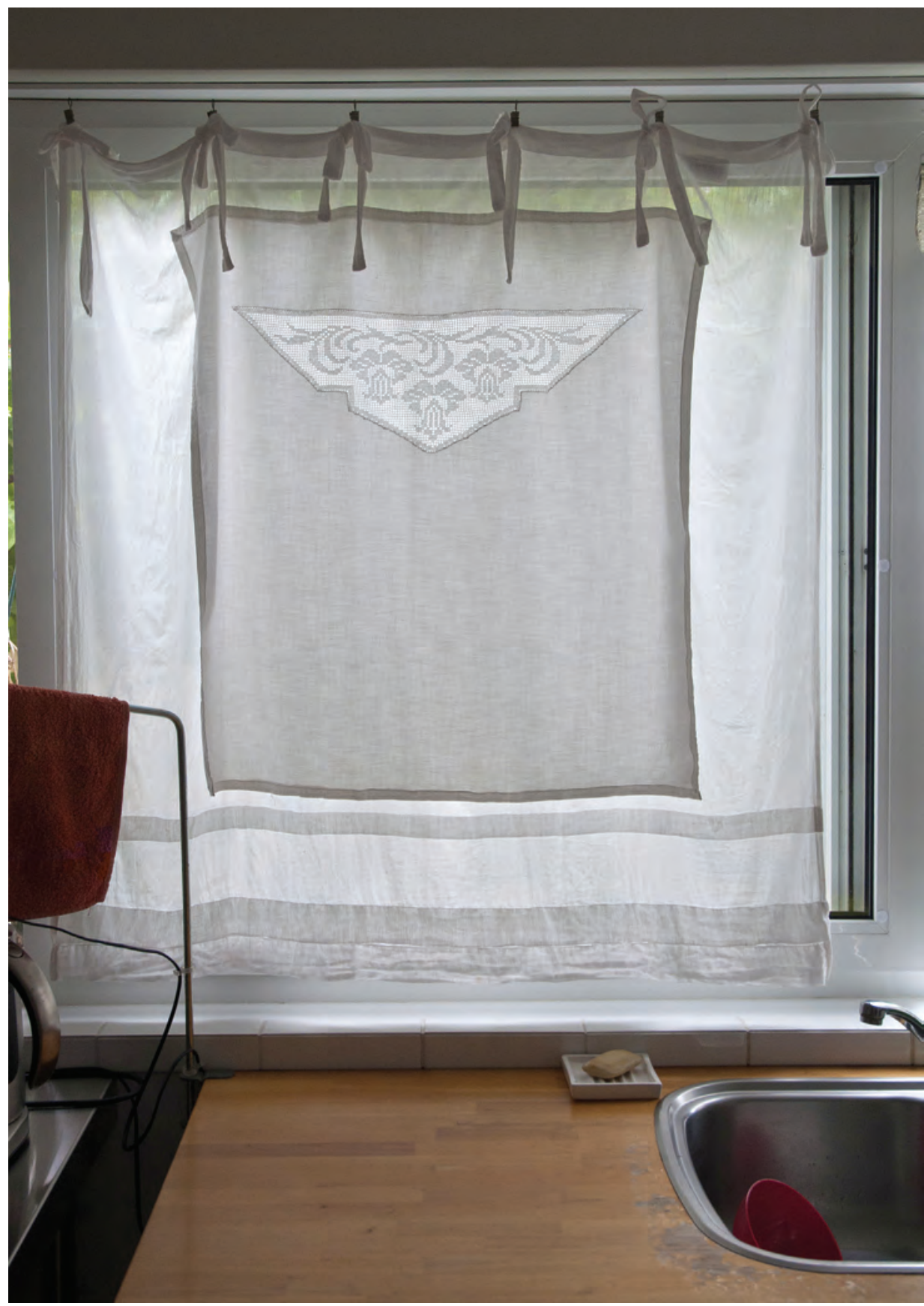

Figure 2. Curtain, n.d., cotton voile, linen pillowcase with crocheted filet lace insert, approx. 1050 x $1100 \mathrm{~mm}$ (pillowcase approx. 800 x $800 \mathrm{~mm}$ ). From the collection of Elisa Markes-Young, gifted from Gisela Plett's linen collection

Photo: Christopher Young 
craft + design enquiry

\section{Repurposing memory \& cloth}

Chapman notes the problem of materials outlasting the life span of a product (2005: 9) and the disposability of items before their functioning life ends (2005: 20). Parkes successfully combats these issues by reclaiming and repurposing fabrics from op shops to generate new and meaningful artworks. Parkes engages with public and private meanings that production, status, economic cost, time, use and ownership ascribe to cloth. During a conversation with the artist (2013a), Parkes explained that employing entirely salvaged fabric adds layers of meaning to his work through the memories of their past. Such materials include handkerchiefs, blankets, pillowcases and clothing that have known and unknown histories.

His work, rest in peace (2011), takes the form of a woollen blanket, cotton sheeting and pillowcase fixed together with lines of repeating and visible hand stitch, while the edges hang loose and expose each layer of cloth. In this work, Parkes refers to the closure and off-shoring of prominent Australian textile manufacturers by allowing the commercial labels on the source textiles to be exposed:

The labels in a work, 'rest in peace', were left visible because they are all companies that either no longer exist or no longer manufacture in Australia ... hence 'rest in peace' was to the memories of these Australian onshore manufacturers ... (Parkes 2013b)

In rest in peace the ghostly memories of once operational factories and places of employment are resurrected and presented as a patchwork of reclaimed fabrics. Parkes mourns, commemorates and revitalises the forgotten quality and status of local manufacturing through his use of labour-intensive stitching and piecing. The mnemonic quality of rest in peace looks at a bygone age whilst reflecting on a burgeoning interest in returning to locally produced goods. The quality of the cloth and the investment of time and handwork gives the work significance and value. The potential of each piece of cloth is restored with this act of salvage and reinvention, ensuring a prolonged existence as an artefact of social commentary. 


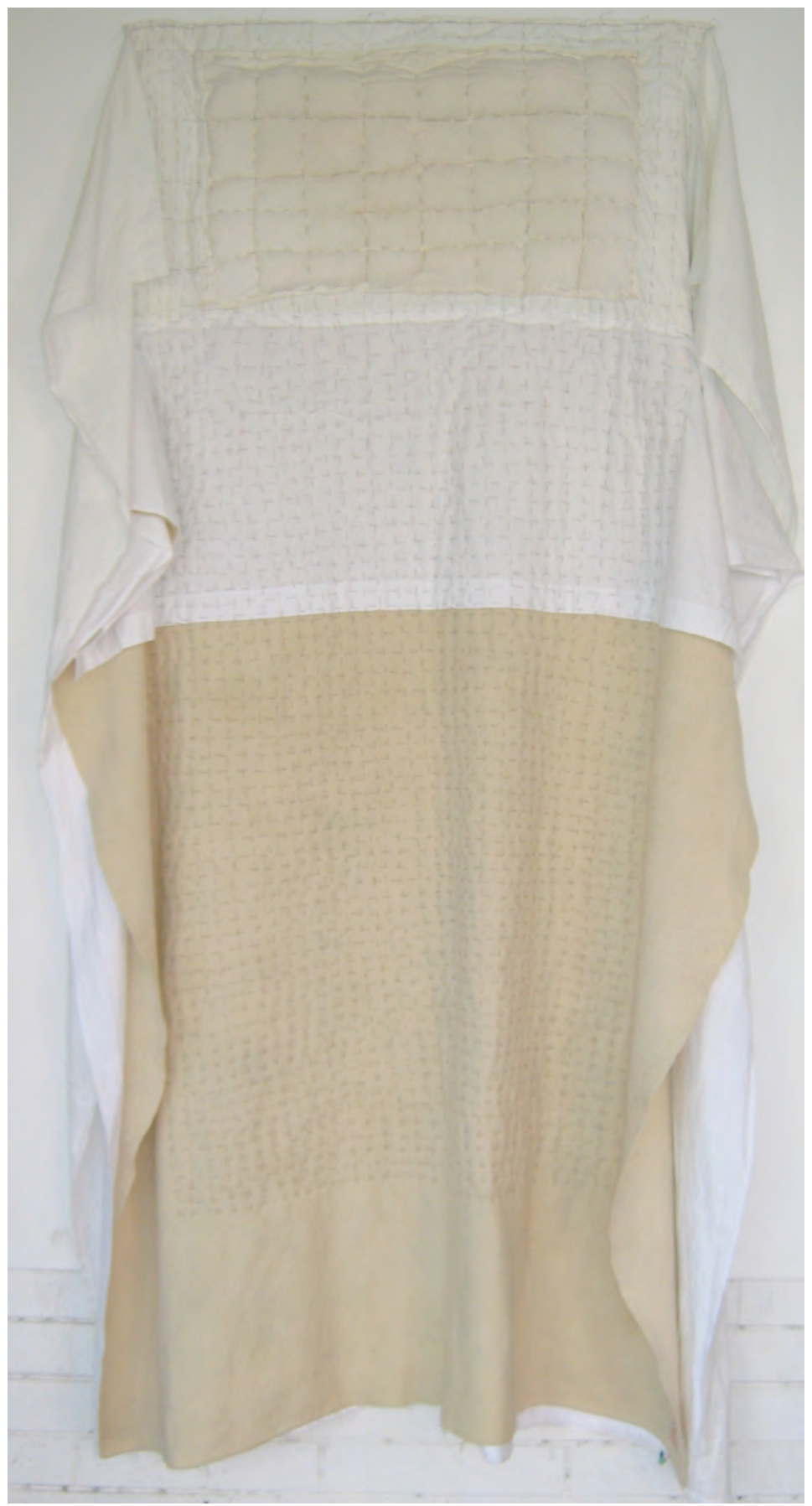

Figure 3. John Parkes, rest in peace, 2011, woollen blanket, cotton sheets, pillowcase, pillow, linen thread, $2480 \times 1280 \mathrm{~mm}$

Photo: John Parkes. Courtesy of the artist 


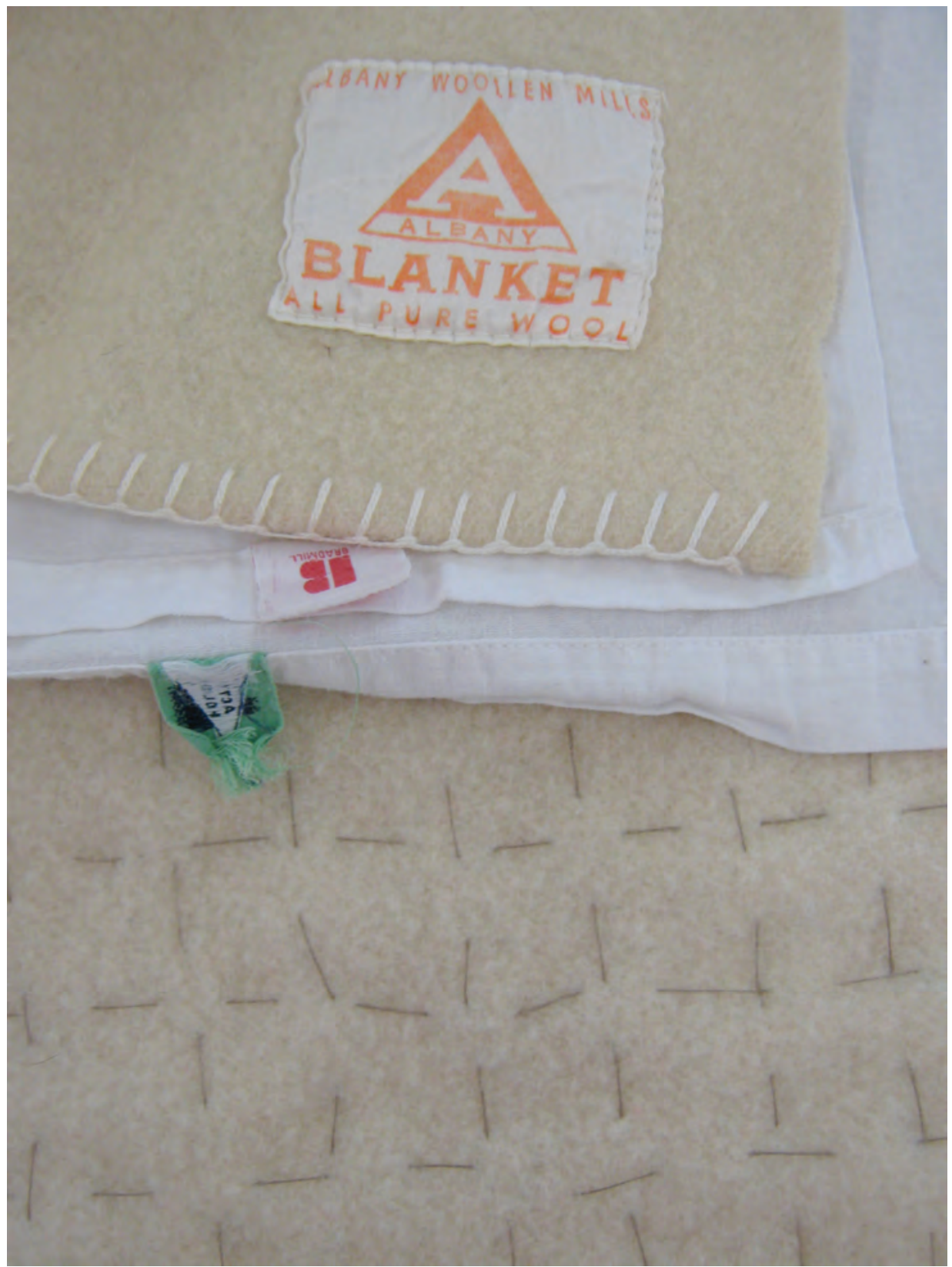

Figure 4. John Parkes, rest in peace (detail), 2011, woollen blanket, cotton sheets, pillowcase, pillow, linen thread, $2480 \times 1280 \mathrm{~mm}$

Photo: John Parkes. Courtesy of the artist

The 2009 work genes/Jean's takes a personal approach to incorporating memory from repurposed textiles. The wall hanging is made from a partial bedsheet bordered by vivid red fabric, filled with numerous layers of fabric 
in between. Parkes lays worn cotton fabrics together and binds them with seemingly haphazard stitching, reminiscent of scrawling text within a diary. Rips, tears and frayed edges are commemorated rather than mended and hidden, suggesting the past histories of the fabrics. The cloth has particular significance to the artist and represents 'My grandmother, my childhood, my adulthood in the cloth, bound together' (Parkes 2013a). The flannelette pyjamas of his childhood lie between a pillowcase that has the literal and metaphorical imprint of his grandmother's cheek and another that was slept upon by the artist when living in Perth. It is at the moment of disintegration that he begins to memorialise the ingrained private meanings, or memories, cultivated over time in his work. 'What is cloth without human contact?' he asks (Parkes 2013a). After the process of making, Parkes intentionally wears or sleeps with the fabric, sometimes for many years, continuing the very personal relationship he has with the textile.

The months and years of wearing, using and stitching the fabrics 'empower[s] them with all of my thinking' (Parkes 2013a). The constant physical engagement with the cloth affixes values of private possession to the original public meanings of the cloth, generating a powerful example of the mnemonic quality of textiles.

The works genes/Jean's and rest in peace demonstrate how cloth can gain worth beyond economic or exchange value. Richins coins the term 'possession meaning' to determine two sources of object value, public and private. He suggests that the private meanings of possessions derive from an object's original public meaning and are then layered with the owner's personal experience of the object. Each person or society forms a unique relationship with objects based upon their individual experiences of the object, 'where the owner's personal history in relation to the object plays an important role' (Richins 1994: 506). These experiences are memories that we tie to the object, establishing it as 'mnemonic', and 'emotionally durable'. Richins's theory of possession meaning can be applied to Parkes's work, which commemorates the layered memories invested in cloth to generate meaningful work of cultural and personal significance. 
craft + design enquiry

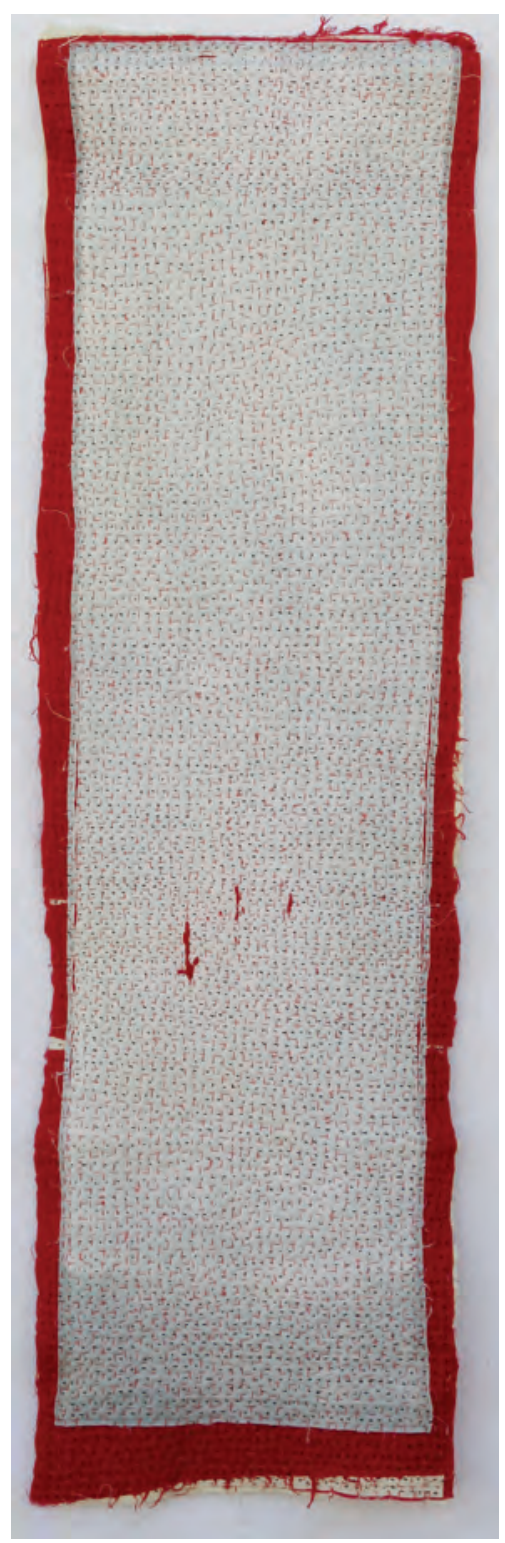

Figure 5. John Parkes, genes/Jean's, 2009, recycled cotton cloth (pillow cases \& pyjamas), cotton \& linen thread, cotton yarn, 1640 x $480 \mathrm{~mm}$

Photo: John Parkes. Courtesy of the artist

\section{Biographical narrative \& identity}

An important aspect of emotionally durable objects is their ability to 'be seen by the user to resonate with and be symbolic of the self' (Chapman 2005: 38). 
Memory's impact upon identity is well documented. It has been confirmed that the integration of past and present selves through memory contributes to the sense of continuity of identity' (Addis \& Tippett 2004). An object that represents some aspect of personal identity through the memories it holds acquires a strong relationship with its owner.

Lindsay's Cinnamon and roses (2004) tapestry was created with personal family memory at the heart of the work. Cinnamon sticks, rose petals, linen, lace, naturally dyed muslin, cotton, and silk intertwine to create an elongated textile. The work's vast length, variegated stripe-work and colour-blocking is recognisable as an evocative timeline. It is only in conversation with Lindsay, however, that the meaning of the work is revealed (Lindsay 2013). The artist discloses the stories she remembers of her grandparents living in Sri Lanka, a place she herself had not visited until recently. The timeline begins in their past and reaches into her present, with each year marked with a new colouration or fabric. Scented materials and recovered fabric from the artist's grandmother's wedding dress are interlaced for a multisensory experience of family heritage that triggers significant memories of birth, death and marriage. Cinnamon and roses (2004) is a catalyst for otherwise unspoken memories delivered through a sensorial record. Like family trees and ancestral records, the tapestry documents past events that continue to impact upon the artist, the collective identity of the artist and her family.

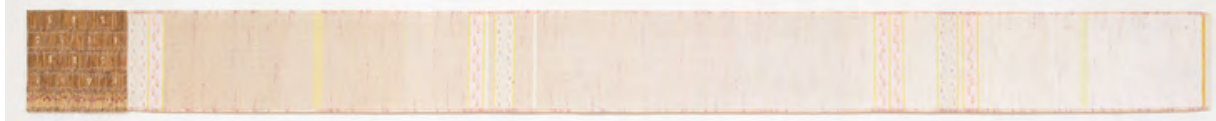

Figure 6. Sara Lindsay, Cinnamon and roses, 2004, cinnamon sticks, rose petals, linen, lace, muslin (dyed with tea and turmeric), cotton, silk, 380 × $4490 \mathrm{~mm}$

Photo: Jeremy Dillon. Courtesy of the artist 


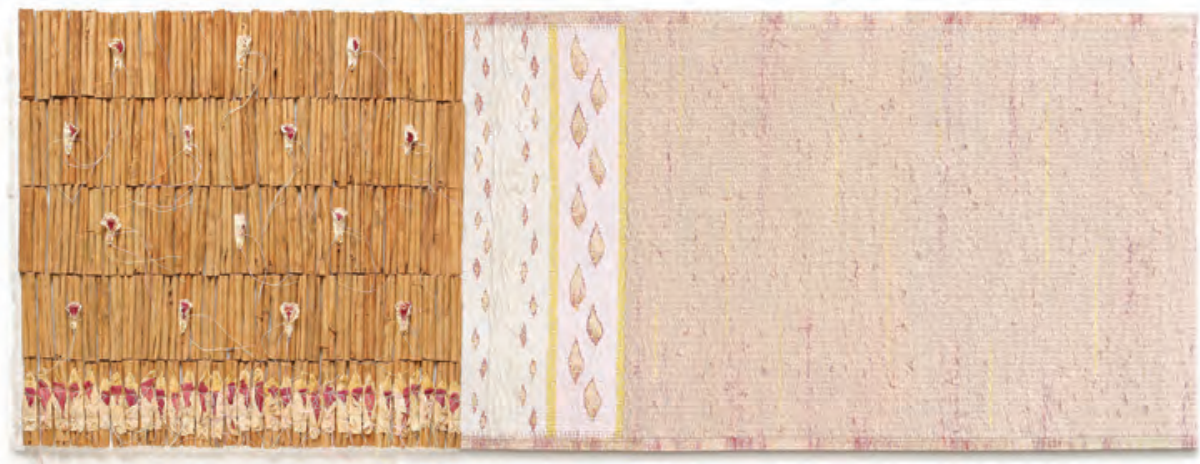

Figure 7. Sara Lindsay, Cinnamon and roses (detail), 2004, cinnamon sticks, rose petals, linen, lace, muslin (dyed with tea and turmeric), cotton, silk, $380 \times 4490 \mathrm{~mm}$ Photo: Jeremy Dillon. Courtesy of the artist

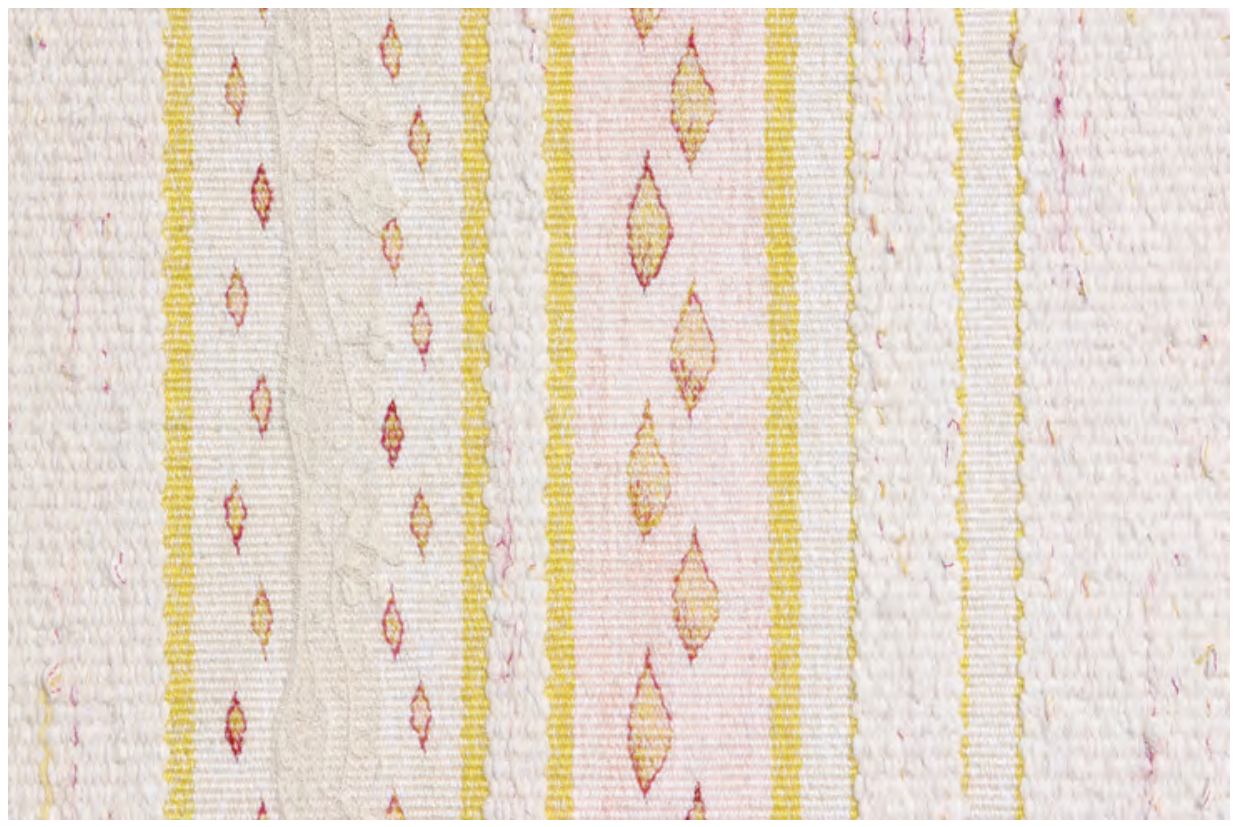

Figure 8. Sara Lindsay, Cinnamon and roses (detail), 2004, cinnamon sticks, rose petals, linen, lace, muslin (dyed with tea and turmeric), cotton, silk, 380 x 4490 mm Photo: Jeremy Dillon. Courtesy of the artist 
The biographic narrative of Cinnamon and roses can be explained in terms of Morin's writing on the 'biographical object'. Morin's journal article, 'L'objet Biographique' (1969, cited in Hoskins 1998: 8-9), classifies objects in terms of their intimate, or detached, relationship with human beings: l'objet biographique (the biographical object) and l'objet protocolaire (the protocol object). Morin argues that biographical objects are those that represent their owner's personality, individuality and life experience. They define time, space and identity for the owner, bearing witness to everyday experiences, and are eternally entwined with their human counterpart (Morin 1969, cited in Hoskins 1998: 8). Conversely, protocol objects, or public commodities are easily replaced, ubiquitous and disconnected from the personal (Morin 1969, cited in Hoskins 1998: 8). They resist the inscriptions of their owner's life, or alternatively, they are not given the opportunity to be so inscribed. I suggest that the biographical object, based upon Morin's work (1969, cited in Hoskins 1998: 8-9), can be given the function to hold, store and reveal personal experiences if the owner chooses. They can also be created for the purpose of securing and documenting memory, as Cinnamon and roses does for Lindsay. The extraordinary skill involved in its making, and the tactile beauty of this piece has led to its being exhibited nationally and internationally. The private memories associated with it remain hidden yet the work resonates strongly with the public audience for its evocation of emotion, indicating that a biographical object embedded with personal memory can operate on both private and public levels. Once retired from exhibition, the piece will remain a significant documentation of identity for Lindsay and her family due to its mnemonic associations and emotional connection.

\section{Memory transference}

A biography is traditionally regarded as a written document. Morin's reference to this word in describing particular objects suggests that a personal narrative can be transcribed by means other than text. The transference of memory to others through writing, spoken words or imagery is complex. Like a trustworthy secret keeper, documents provide a space where personal narratives are shared only with the permission of their owner. Without specific direction the significance, detail and emotional milieu of a memory can be misplaced. This problematises how it is possible to inherit or adopt another's biographic object. We cannot spontaneously adopt the same emotional connection towards the object as the original unknown owner. Wear, scratches, fading or damage may suggest that the object was well-loved, but we must build and bestow our own experiences upon the object to form an emotionally durable relationship with it.

It is possible for humans to forge meaningful attachments to objects with unknown histories, as revealed in conversation with artist Ilka White (2012). An incomplete patchwork bedspread holds memories of rest and renewal for the artist. This quilt was found by chance in a second-hand shop. Bright fabric hexagons of 1940s, 1950s and 1960s prints were semi-stitched in place by an anonymous maker of unknown origins. Some still have backing cardboard 
cut from old cereal boxes, held in place with tacking stitch waiting to be removed. The traces of the making process that are still visible in the quilt hint at the abilities of its maker, but do not retain any other details regarding the identity of the maker. The workmanship and skill in the quilt was immediately recognised by White, who purchased it and later used it on her own bed. During a concentrated period of recovery from major illness the bedspread became a constant companion. Despite the unknown origins of the quilt, White developed an emotional connection with the item. She speaks intimately about this period in her life:

I have very fond memories of the beautiful early morning winter sun, coming from the east through these windows, and my bed was right there, my head was just where those pillows are. And the sunlight at that time of morning in the winter was absolutely beautiful (and) it would come in on that bedspread, so I have very pure memories. My mind was still recovering so I wasn't thinking much further than my present tense. I spent almost two months almost entirely in the present tense and it was so delightful. All that caught my attention in those moments for those months was the sunlight, the bedspread, the colours, the joyful flowery nature of it, and my being. Full stop ... That was really amazing. I hadn't realized, I don't think, creatively how important that rest was until some months after I recovered enough to be out of bed and getting back into my life. (White 2012)

Through White's experience of respite, recovery and revival, the quilt became a valued possession. Through constant visual and physical contact with the quilt, it became imbued with the sensory memories she describes. The emotional durability associated with the patchwork quilt is a consequence of these embedded memories. The capacity for textiles to transfer existing and embed new memories remains an important reason for why the artist treasures this and other similar textile artefacts within her collection.

\section{Object and owner relationships}

White's patchwork quilt is an example of the way in which bonds are made with objects that are associated with significant experiences, adding to the purely practical or ornamental role of the object. The fragile and affective relationship between owner and object is full of meaning and can be useful for maintaining self-identity during times of upheaval. This brings a sense of comfort and security, highlighting another valuable quality of the mnemonic object. 


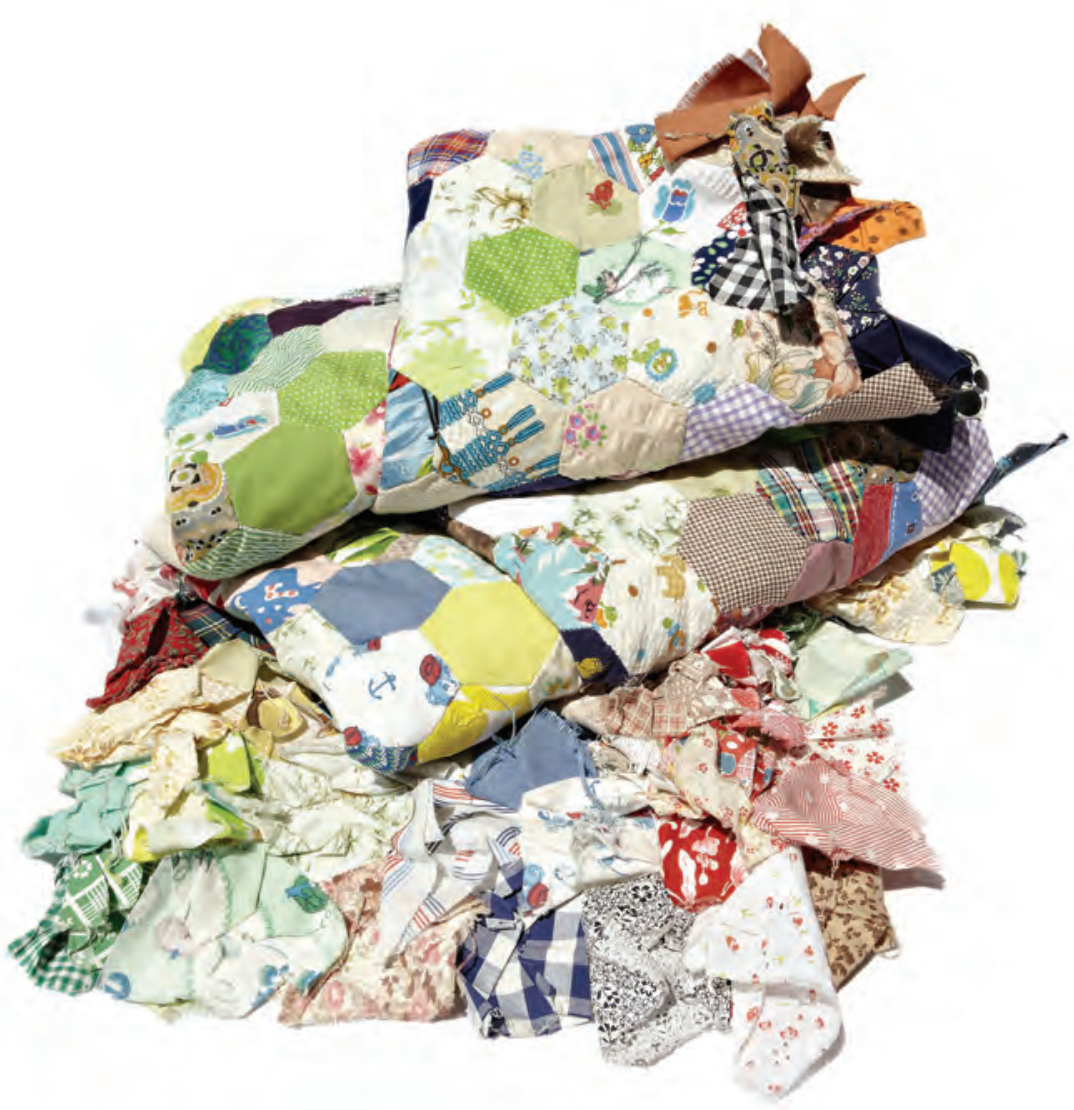

Figure 9. Unknown artist, Patchwork quilt, n.d., cotton fabric, cotton thread, cardboard backing pieces, $1800 \times 2100 \mathrm{~mm}$

Photo: Danielle Chau

The theory of 'transitional objects', developed by Winnicott, (1984: 229-42), presents an example of an affective relationship between possession and possessor that correlates with White's relationship with her patchwork quilt. The psychoanalyst and paediatrician focused his research upon childhood attachment to certain objects, characteristically soft blankets or toys, and their capacity to calm and comfort. Winnicott saw these transitional objects as an aid in the child's growing perception of the inner and outer world (1984: 242). His focus is on a period of change and upheaval in the child's development, in which she/he is beginning to understand external reality, to gain a sense of 'objective perception' and the 'capacity to create, think up, devise, originate, [and] produce an object' (1984: 230). The transitional object plays an important 
role in navigating these changes as it 'gives room for the process of becoming able to accept difference and similarity' (Winnicott 1984: 234). The object, via haptic playfulness and illusion, provides continuity and consistency during periods of disruption. The relationship between the child and the transitional object ultimately enables a sense of calm, develops individual identity and fosters creative imagination whilst change is occurring (Winnicott 1984: 242).

The types of objects used by children, such as blankets, pillows and toys, are most often textiles and have characteristics that promote a strong sensorial and emotional attachment. When asked to describe their objects, children often mention texture as a primary quality (Lehman et al. 1995: 443-59). Touch is the initial sensation developed during infancy, where the skin is a receptor for experience and perception of the world (Delong et al. 2007: 38). Haptic, or bodily, engagement with soft materials may remind the child of a parent's skin, which is associated with wellbeing and security. The tactile interaction with transitional objects is often repetitive and habitual (rubbing, twisting, stroking), encouraged by the pleasant sensation of softness. A cognitive and affective response is evoked through such engagement and cultivates a strong relationship between the child and their object.

The transitional object, or what Lehman, Arnold \& Reeves name the attachment object (1995: 443-59), has qualities that are entirely unique, particularly from the perspective of the child. The object is frequently regarded as distinctive in physical character and absolutely irreplaceable due to the experience it engenders. This perception can be so extreme that if the object is washed, it no longer has the potency that it once did. Time spent together and the conferring of experience as memory to the object further cements attachment, making it an essential aspect in our constantly shifting lives.

I suggest that objects can provide emotional grounding during any period of transition, not only in childhood. White's relationship with her patchwork quilt embodies characteristics of the transitional object through the physically intimate contact established between the quilt and White's body, and the way in which her relationship with the quilt was able to provide comfort during a time of emotional adjustment. The associated reaffirming memory of rest and resilience can also provide White with a grounding reminder of her own capacity to journey through and out of a difficult period, providing a representation of both vulnerability and strength that offers a meaningful, visceral and affective connection that can continue to reassure during similarly challenging circumstances in the future.

\section{Mnemonic objects \& affect}

In understanding how mnemonic qualities enhance the emotional durability of an object, we can begin to consider how we might design and create such robust items. Chapman admits that once the object is out in the world, it is difficult to influence how the object is valued and used. 
It is clear that although a designer can certainly elicit within users an emotional response to a given object, the explicit nature of the response is beyond the designer's control; the unique assemblage of past experiences that is particular to each user; their cultural background and life journey determine this. (Chapman 2005: 100)

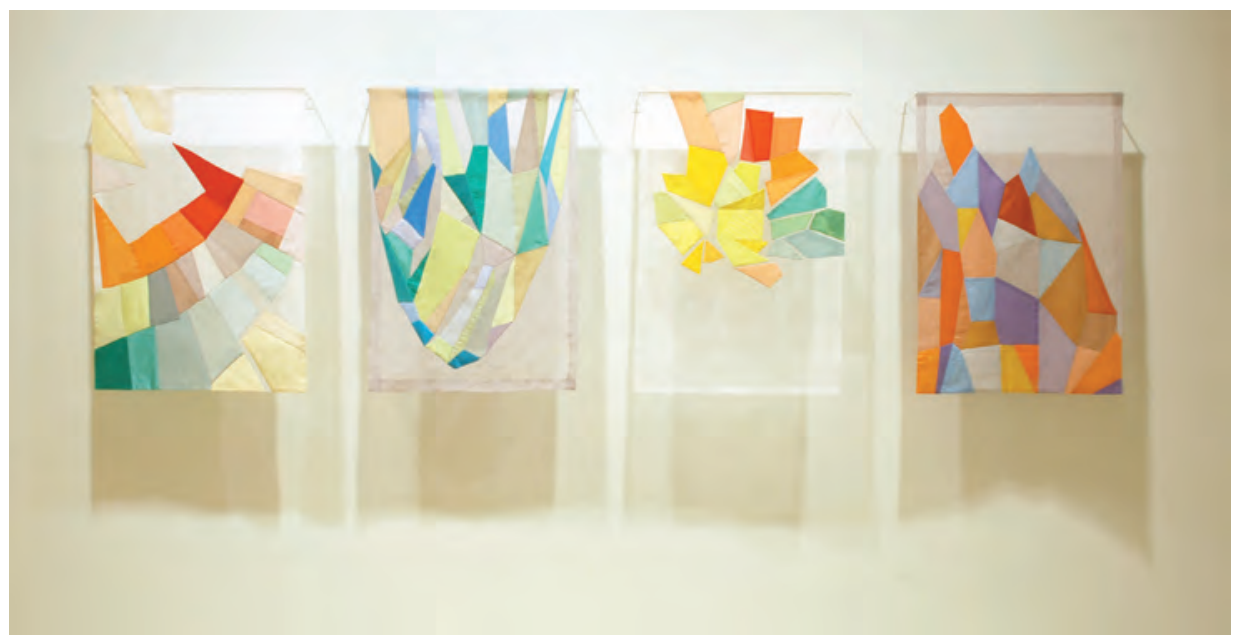

Figure 10. Ilka White, Spring Summer 11/12, 2011-2012, silk organza, inherited fabrics, thread, cloth collage (appliqué), each piece $920 \times 630 \mathrm{~mm}$

Photo: Ilka White. Courtesy of the artist

The patchwork quilt became influential to White's subsequent body of work, Spring Summer 11/12 (2013). In this series of wall hangings, cotton appliqué tessellates across gossamer silk organza. Hues range from sun-bleached pales to permeated brights. Each fabric segment comes from the artist's inherited collection of fabric and was instinctively positioned and placed (White 2012). There are qualities of handwork, piecing, intuition, segmentation, and hue that the pieces share. More importantly, both the patchwork quilt and Spring Summer 11/12 represent White's unique memories of a critical time in her life and her re-emergence into her practice after some years. She describes her process and thoughts of creating Spring Summer 11/12:

And so what felt possible started to be laying out my inherited fabrics from my grandma and looking at what it suggested being made into. It ended up being made into a series of hangings, applique fabric collage. Which was very different from the way I had worked previously. Aesthetic, palette and technique and everything. I was surprised as anybody. Even as I was making it, it felt like I was channeling something for elsewhere. Even as every piece went down, and even when I decided it was 'right' and it stayed there I thought, 'Fancy that being right! Who'd of thought?' It was a strange creation time. (White 2012) 
White's emotional relationship with the patchwork quilt influenced the making of Spring Summer 11/12, which became a reflection on her return to health. The wall hangings are a tangible response to her convalescence and recovery. White also tells, however, of their 'universal appeal' (White 2012) while on show. This appeal is reflected in the fact that the hangings were purchased by collectors and so have a meaningful life beyond that attributed to them by the artist. It is evident that their composition, fabrication and palette allude to White's story, but are also able to produce an emotional response from others. It is the affective response to concepts of memory that maintains their survival in a new context.

\section{Conclusion}

In a world already groaning with the burden of disposable objects and manufactured waste, how can we responsibly create new 'things'? We cannot keep generating objects with tenuously short-term life cycles to the detriment of the earth's resources. Likewise, we cannot quell our natural instinct to create, make and consume. The responsibility lies with designers, artists, makers, consumers and collectors to rethink how we generate and respond to objects and the consequent relationships we have with them.

Chapman's theory of emotionally durable design allows us to understand that the sustainability of an object does not stop with the designer. It can be perpetuated through the emotional relationship a person has with an object. Memory is an important component to building such a relationship, as the work of Markes-Young, Parkes, Lindsay and White demonstrate. The evocation of memory through cloth can be addressed by textile practitioners in manifold ways to achieve a variety of registers. Repurposed cloth presents undisclosed meanings that are developed and supplemented with the intervention of textile practitioners. Family history is conveyed through the adaptation of inherited textiles, made apparent by Markes-Young's tablecloth and curtain. The original public meaning of cloth is supplemented with intense haptic engagement to comment upon the value of textiles, as by Parkes. Reflection upon family memory through interlacing of inherited fragments with non-traditional textiles is demonstrated by Lindsay's Cinnamon and roses. Finally, new textiles can be inspired by significant transitional life stages, attested in White's work, Spring Summer 11/12. Each artist ascribes memory to their work in distinctive and varied ways.

The textiles discussed in this paper are a testament to the creative approaches used to embed cloth with memory. The making of mnemonic textiles provides a rich and meaningful field to explore for the benefit of sustainable creation of artefacts. Textiles' haptic nature, proximity to the body and the time invested in creating them elevates their possession value. This value goes beyond the economic by authenticating and sustaining our identity through the memories they represent and, in turn, we work to preserve them. 
Emma Peters is a textile practitioner, researcher and lecturer, currently completing her Masters of Design (Hons) at The College of Fine Arts, University of New South Wales. Her background lies in commercial textile design work for Sydney's leading home-ware design studios. Emma explores material culture, memory and sustainability, and utilises theoretical models in combination with low and hi-tech making processes to bring new understanding to these areas.

\section{References}

Addis, D.R. \& Tippett, L.J. 2004, 'Memory of myself: Autobiographical memory and identity in Alzheimer's disease', Memory, 12, pp. 56-74.

Belk, R.W. 1990, 'The role of possessions in constructing and maintaining a sense of past', Advances in Consumer Research, 17, pp. 669-76.

Bennett, J. 2003, 'The aesthetics of sense-memory: Theorising trauma through the visual arts', in I.S. Radstone \& K. Hodgkin (eds), Regimes of Memory, New York: Routledge.

Buchanan, T.W. \& Adolphs, R. 2004, The Neuroanatomy of Emotional Memory in Humans. Memory and Emotion, Oxford; New York: Oxford University Press.

Chapman, J. 2005, Emotionally Durable Design: Objects, Experiences and Empathy, London; Virginia: Earthscan.

Delong, M., Juanjuan, W. \& Mingxin, B. 2007, 'May I touch it?', Textile: The Journal of Cloth \& Culture, vol. 5, no. 1, pp. 34-49, viewed 15 November 2012, http://search.ebscohost.com.wwwproxy0.library.unsw.edu.au/login. aspx?direct=true\&db=vth\&AN=24909623\&site=ehost-live.

Hoskins, J. 1998, Biographical Objects: How Things Tell the Stories of People's Lives, New York: Routledge.

Kwint, M., Aynsley, J. \& Breward, C. 1999, Material Memories: [design and evocation], Oxford: Berg.

Lehman, E.B., Arnold, B.E. \& Reeves, S.L. 1995, 'Attachments to blankets, teddy bears, and other nonsocial objects: A child's perspective', The Journal of Genetic Psychology, vol. 156, no. 4, pp. 443-43, viewed 14 November 2012, http://search.proquest.com.wwwproxy0.library.unsw.edu.au/docview $/ 228502042$ ? accountid=12763.

Lindsay, S. 2013, interview with the author, 13 February.

Markes-Young, E. 2013, interview with the author, 20 March.

Mcdonough, W. \& Braungart, M. 2002, Cradle to Cradle: Remaking the Way we Make Things, New York: North Point Press. 
Nora, P., 1989, 'Between memory and history: Les Lieux de Mémoire', Representations, no. 26, pp. 7-24.

Papanek, V.J. 1985, Design for the Real World: Human Ecology and Social Change, London: Thames and Hudson.

Parkes, J. 2013a, interview with the author, 16 December.

- 2013b, email communication with the author, 29 July.

Philippe, F.L., Koestner, R., Lecours, S., Beaulieu-Pelletier, G., Bois, K., Philippe, F.L., Koestner, R., Lecours, S., Beaulieu-Pelletier, G. \& Bois, K. 2011, 'The role of autobiographical memory networks in the experience of negative emotions: How our remembered past elicits our current feelings', Emotion, 11, pp. 1279-90.

Richins, M.L. 1994, 'Valuing things: The public and private meanings of possessions'. Journal of Consumer Research, vol. 21, no. 3, pp. 504-21, viewed 22 January, http://search.ebscohost.com/login.aspx?direct=true\&d $\mathrm{b}=\mathrm{buh} \& \mathrm{AN}=9501161817 \&$ site=ehost-live.

Rowlands, M. \& Tilley, C. 2006, 'Monuments and memorials', in C. Tilley (ed.), Handbook of Material Culture, London; Thousand Oaks: SAGE.Stewart, S. 1984, On Longing: Narratives of the Miniature, the Gigantic, the Souvenir, the Collection, Baltimore: Johns Hopkins University Press.

White, I. 2012, interview with the author, 13 December.

- - 2013. Ilka White, viewed 2 July, http://ilkawhite.com.au.

Winnicott, D.W. 1984, Through Paediatrics to Psychoanalysis, 23rd edn, London: Karnac. 
This text taken from craft + design enquiry issue 6, 2014, Craft.Material. Memory, Edited by Anne Brennan and Patsy Hely, published 2014 by ANU Press, The Australian National University,

Canberra, Australia. 